\title{
¿Se Debe Considerar la Afectación Neurológica en la Infección Por SARS-CoV-2?
}

\section{Should Neurological Affection Be Considered In SARS-CoV-2 Infection?}

Jose David Sáenz-López, Keyner Enrique Tatis-Villamizar, Leyder Moisés Romero-González

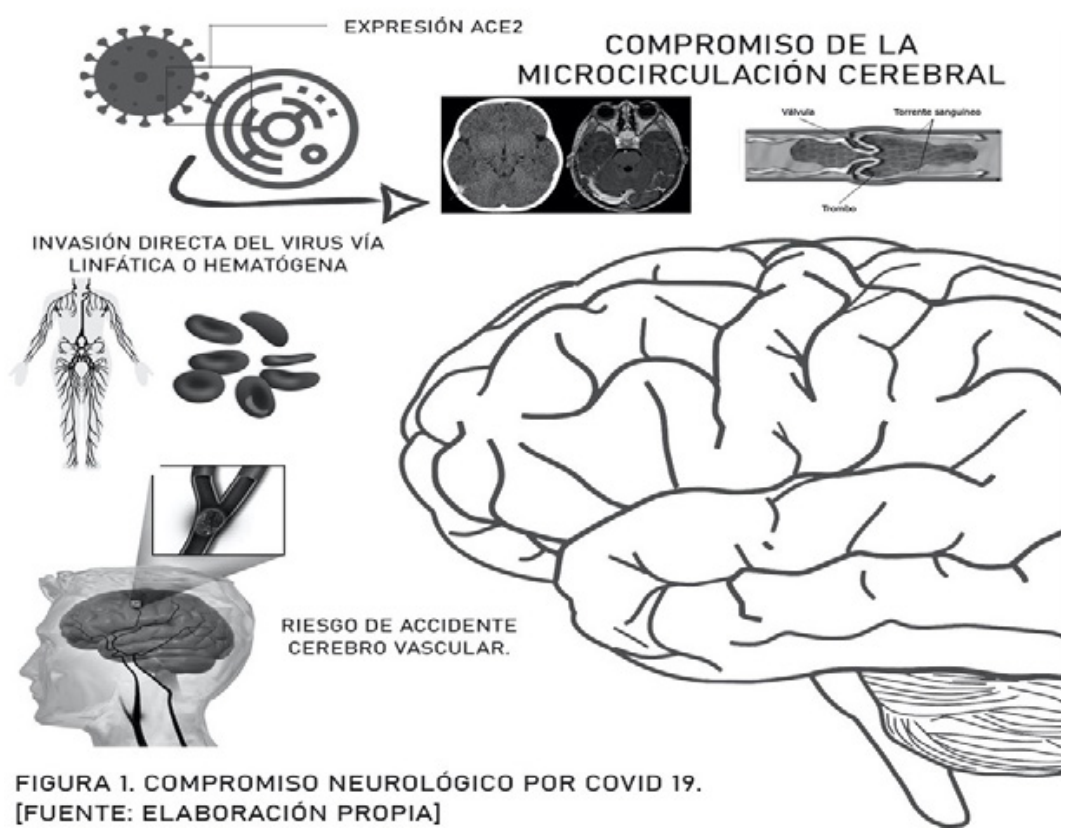

Figura 1. Figura 1. Compromiso neurológico por COVID-19. [Fuente: elaboración propia].

Estimada Editora:

Se ha especulado sobre la afectación neurológica en la infección por COVID-19, a pesar de ser un virus con predilección por el epitelio respiratorio. Por consiguiente, la forma en que afecta al sistema nervioso central (SNC) no está bien dilucidado, puesto que las hipótesis existentes se basan en datos extrapolados de otros coronavirus. Sin embargo, cabe resaltar que el mecanismo infeccioso del SARS-CoV-2 (Figura 1) podría afectar directa o indirectamente, lo que plantea la pregunta si realmente compromete el SNC o solo las funciones neurológicas. Aunque la expresión de la ACE2 es baja en el cerebro, los estudios de autopsia han demostrado previamente la presencia de partículas de SARSCoV-2 en el tejido cerebral. ${ }^{2}$ Se han propuesto mecanismos en los que la enfermedad de COVID-19 altera el SNC. La hipótesis principalmente aceptada se basa en la expresión de ACE2 en el endotelio vascular compro-
Universidad del Sinú Seccional Cartagena, Cartagena de Indias, Colombia.
Correspondencia:

José David Sáenz López

Dirección: Universidad del Sinú Seccional Cartagena.

Teléfono :(+57) 3218691312.

Email: josedsaenzlopez@hotmail.com

https://orcid.org/0000-0002-0987-6741 
metiendo la microcirculación cerebral. Igualmente se ha estudiado la posibilidad de invasión directa del virus por vía linfática o hematógena, no obstante, no existe evidencia que respalde esta hipótesis.

Clínicamente se ha demostrado en pacientes con síntomas de COVID-19, como dolor de cabeza, anosmia y ageusia, que ocurren durante la etapa temprana de la enfermedad y su función de progresión como una característica de alerta significativa de COVID-19. Además, se han informado numerosos casos en algunos pacientes con complicaciones psiquiátricas por el virus, con alteración de la conciencia y encefalopatía.

El vínculo existente de COVID-19 con afecciones neurológicas sin un mecanismo de invasión confirmado se cuestiona actualmente, por lo que se debe promover la génesis de estudios que demuestren un posible vínculo causal de afecciones neurológicas secundarias infección por SARS-CoV-2/COVID-19.

\section{Referencias}

1. Carod-Artal FJ. Neurological complications from coronavirus and COVID-19. Neurol Rev (2020); 70: 311-22. doi: 10.33588/rn.7009. 2020179.

2. Mao L, Jin $\mathrm{H}$, Wang $\mathrm{M}, \mathrm{Hu} \mathrm{Y}$, Chen $\mathrm{S}, \mathrm{He}$ Q, et al. Neurological manifestations of patients hospitalized with coronavirus disease 2019 in Wuhan, China. JAMA neurology,e201127. (2020); doi: 10.1001/jamaneurol.2020.1127

3. Wilson MP, Jack AS. Coronavirus disease 2019 (COVID-19) in neurology and neurosurgery:A scoping review of the early literature. Clin Neurol Neurosurg. (2020);193:105866. doi:10.1016/j.clineuro.2020.105866

4. Whittaker A, Anson M, Harky A. Neurological Manifestations of COVID?19: A systematic review and current update. Neurologic Act Scandinavica. (2020); doi: 10.1111/ane.13266 